\title{
ANTI-MICROBIAL ACTIVITIES OF ENDURACIDIN (ENRAMYCIN) IN VITRO AND IN VIVO
}

\author{
Masaya Kawakami, Yutaka Nagai, \\ Toshio FujII and Susumu Mitsuhashi \\ Department of Microbiology, School of Medicine, \\ Gunma University, Maebashi, Japan
}

(Received for publication February 12, 1971)

\begin{abstract}
Enduracidin (enramycin) was found to have high order of antibacterial activity against various antibiotic-resistant strains of staphylococci, and to be free of cross-resistance with antibiotics commercially available at present. This drug was proved to be ineffective against dysentery bacillus and other gram-negative bacilli. It is believed to be an agent to which bacterial resistance hardly increases. The $50 \%$ effective dose $\left(\mathrm{ED}_{50}\right)$ of enramycin in experimental Staphylococcus aureus infections in mice was proved to be 2.27 $\mathrm{mg} / \mathrm{kg}$.
\end{abstract}

Enduracidin is a new antibiotic of peptide type which is produced by Streptomyces fungicidicus B-5477. Bacteriological and clinical investigations of this antibiotic were reported in earlier papers ${ }^{1,2,3)}$. Recently enduracidin preparation has been further purified, and the present study is a report on some bacteriological examination in vitro and in vivo of this sample.

\section{Materials and Methods}

(1) Test agent: One gram of enduracidin supplied by the Takeda Chemical Industries $(1,008 \mathrm{mcg}$ potency per $\mathrm{mg}$ ) was dissolved in $40 \mathrm{ml}$ of $70 \%$ methyl alcohol as the stock solution, and this stock solution was appropriately diluted with $0.85 \%$ sodium chloride at the time of use.

(2) Test microorganisms: One hundred strains, taken at rondom from about 6,000 strains of staphylococci isolated from lesions in man, and maintained by the Research Committee on the Drug-Resistance of Staphylococci (Chief: Dr. TokujI Ichiкawa), were used. These strains belong to various phage types and show different patterns of resistance to antibiotics, including kanamycin, chloramphenicol, macrolide group antibiotics, synthetic penicillins, and cephalosporins. Six strains of dysentery bacilli of different serum types and of various resistance patterns, were selected from 10,000 strains isolated by the Research Committee for Drug-Resistant Shigella strains (Chief: Dr. Tadato Ezaki), and which are maintained in our laboratory. Nineteen strains of gram-negative rods other than dysentery bacilli were selected out of the representative multiple antibiotic-resistant strains isolated by the Research Committee of Gram-negative Bacteria (Chief : Prof. SHunJI IsHIYAMA), and which are maintained in our laboratory.

$S$. aureus KS 184-5, used in infection experiments, was isolated from a human lesion and maintained in our laboratory. The maximal concentration of enduracidin compatible with growth of this strain was found to be $0.013 \mathrm{mcg}$ potency $/ \mathrm{ml}$, thus, this strain is considered as sensitive. The $\mathrm{LD}_{50}$ of this strain in mice, by intravenous infection, was found to be about $6 \mathrm{mcg}$ dry weight (about $2 \times 10^{7}$ viable cells). 
(3) Determination of sensitivity: The minimal inhibitory concentration was determined by the standard method set up by the Japan Society of Chemotherapy. The bacteria were cultured in peptone-water medium for 18 hours, and one loopful of 100 timesdiluted culture was dropped onto heart infusion agar (Nissui Pharmaceutical Co.) plates containing various concentrations of enduracidin (two fold serial dilutions). The minimal inhibitory concentration (MIC) is the lowest concentration of the test antibiotic at which any inhibitory effect is observed.

(4) Test on the acquirement of resistance: Four strains of staphylococci of human origin (S-931, S-1307, S-1367, and MS-353) and the reference strain of S. aureus FDA $209 \mathrm{P}$, were cultured overnight in a brain heart infusion (BHI) broth. One loopful (about $10^{6}$ bacterial cells) was inoculated into BHI broth containing various concentrations of enduracidin which were then incubated for 18 hours. One loopful of cells was taken from the broth containing maximal concentration of the drug permitting growth, and inoculated in fresh broth containing higher concentrations of enduracidin. This procedure was repeated serially 10 times for examination of the increase in resistance of bacteria to the test antibiotic.

(5) Infection and treatment: Male and female DDN mice, weighing 20 23.5 g, were used. About 12 mice were kept in each cage, fed with mouse diet $\left(\mathrm{NF}_{1}\right.$ tablets, Oriental Yeast Co., Tokyo) and given tap water; the room temperature was maintained at $20 \sim$ $24^{\circ} \mathrm{C}$. Mice were infected with $S$. aureus KS $185-4$ by an intravenous injection of $50 \mathrm{mcg}$ (ca. $8 \mathrm{LD}_{50}$ ) of viable cells and deaths were recorded for 7 days. The 24 mice in the untreated group all died within 4 days. Various amounts of the drug were administered subcutaneously to groups of mice, each consisting of $22 \sim 40$ animals, 60 minutes after the infection. The Litchfield and Wilcoxon's method ${ }^{4)}$ was used for the assessment of the therapeutic effect, calculating the $50 \%$ effective dose $\left(\mathrm{ED}_{50}\right)$ from the survival rate, and its $95 \%$ confidence limits.

\section{Results}

In Vitro Effectiveness of Enduracidin

As shown in Fig. 1, the minimal inhibitory concentration against 100 strains of staphylococci was found to have a distribution with a sharp peak at $0.1 \mathrm{mcg} / \mathrm{ml}$. The bacteria used in this study are resistant to many antibiotics (see Materials and Methods), but in none of these resistant strains, crossresistance to enduracidin was demonstrated. On the other hand, enduracidin was found to be completely inactive at $100 \mathrm{mcg} / \mathrm{ml}$ against the gram-negative rods tested (4 strains of Salmonella, 6 strains of Shigella, 5 strains of Escherichia and 2 strains of each of Arizona, Proteus, Pseudomonas, Klebsiella and Vibrio) irrespective of their resistant patterns to the other antibiotics.

Development Resistance by Staphylococci to Enduracidin

The resistance of microorganisms could be somewhat increased by successive transfers to culture media containing increasing amount of enduracidin (Fig. 2). The MIC was raised $0.4 \mathrm{mcg} / \mathrm{ml}$ after $6 \sim 10$ successive trans-

Fig. 1. Distribution of Staphylococcus aureus possessing: different susceptibility to enduracidin.

One hundred strains of S. aureus of human origin with various antibiotic resistance patterns were used.

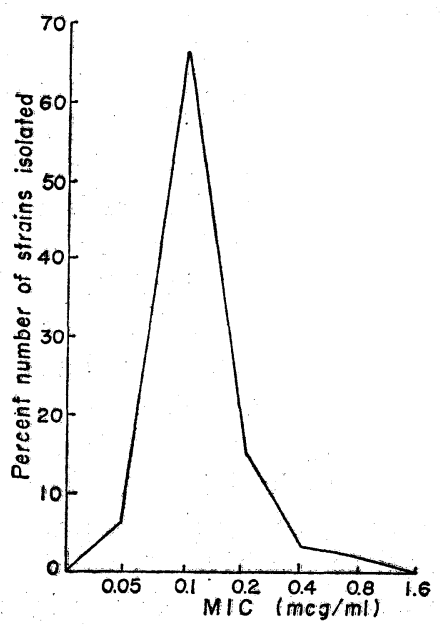


fers. This resistance was, however, found to be highly labile, because the MIC of resistant populations fell to the original level when the microorganisms were incubated on an enduracidin-free medium for 18 hours. The unstable resistant cells are likely to exhibit a phenotypic type of resistance, although they might be mutants with a very high rate of back-mutation. In any case, they differ from streptomycin and kanamycin resistant mutants.

\section{In Vivo Activity}

In the two preliminary experiments using respectively 64 and 88 mice weighing $21.4 \pm 0.84 \mathrm{~g}$, the following results were obtained : $\mathrm{ED}_{50}=1.26,95 \%$ confidence limits $=0.82 \sim 1.96$, and $\mathrm{ED}_{50}=2.67,95 \%$ confidence limits $=1.71 \sim 4.76(\mathrm{mg} / \mathrm{kg})$. Then we carried out an experiment of larger scale as follows: a total of 164 mice, weighing $21.3 \pm 0.13 \mathrm{~g}$ were infected with $S$. aureus and divided into five groups (the unbiased estimate of population variance of body weight was 99.03 inside each group, and 0.0212 between groups, and the variance ratio $\mathrm{F}=0.015$; so there was no significant difference between groups), and they were treated with different amounts of enduracidin. The survival rates, summarized in Table 1, were plotted on a log dose-probit sheet as shown in Fig. 3. A regression line, $Y=$ $a+b X$, where $a=2.14, b=4.37$, was calculated from the plots by the least square method.
Fig. 3. Protective effect of enduracidin in an acute Staphylococcus aureus infection in mice.

The results in Table 1 were plotted.

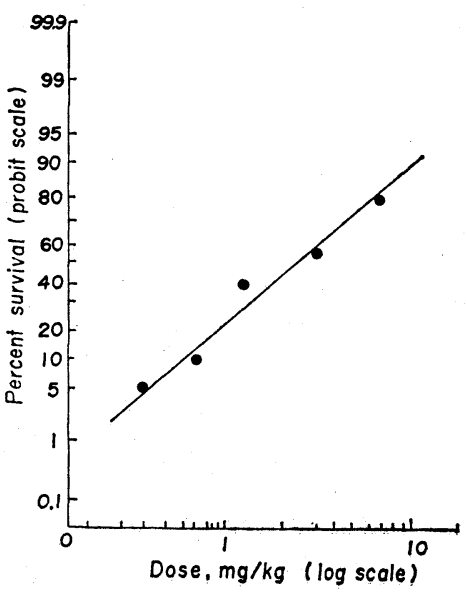

Fitness of the regression line to these points was examined by $\chi^{2}$ test and $\chi^{2}=1.44$ was obtained. Since $\chi_{9_{5}(3)}^{2}=9.35$, these points may be said to be well on a straight line. An $\mathrm{ED}_{50}$ of $2.27 \mathrm{mg} / \mathrm{kg}$ was obtained from this straight line, with the confidence limits of $1.69 \sim 3.06 \mathrm{mg} / \mathrm{kg}$.

Table 1. Protective effect of enduracidin in an acute Staphylococcus aureus infection in mice

\begin{tabular}{c|c|c|c}
\hline $\begin{array}{c}\text { Does of drug } \\
(\mathrm{mg} / \mathrm{kg})\end{array}$ & $\begin{array}{c}\text { Number of } \\
\text { mice tested }\end{array}$ & $\begin{array}{c}\text { Number of } \\
\text { survivors }\end{array}$ & $\begin{array}{c}\text { Survival } \\
\text { rate (\%) }\end{array}$ \\
\hline 0.375 & 40 & 2 & 5 \\
0.75 & 24 & 3 & 12.5 \\
1.5 & 40 & 16 & 40 \\
3 & 22 & 13 & 59.1 \\
6 & 38 & 31 & 81.6 \\
\hline
\end{tabular}

Mice were injected intraperitoneally with $50 \mathrm{mcg}$ of $S$. aureus $\mathrm{KS} 185-4$ (about $8 \mathrm{LD}_{50}$ ), and were treated by a subcutaneous injection with varying amounts of EDC, 60 minutes after the infection. The survivors were scored at 7 th day of infection.

\section{Discussion}

Enduracidin was uniformly active against multiple antibiotic-resistant strains of staphylococci, with a sharp peak of MIC distribution at $0.1 \mathrm{mg} / \mathrm{ml}$, and it was free of 
cross resistance with other antibiotics. This is in agreement with the results reported by earlier workers ${ }^{1,2)}$. We have previously demonstrated that microorganisms do not readily acquire resistance to such peptide-like antibiotics as colistin and mikamycin ${ }^{5}$. In this respect, present experiments showed that enduracidin is not an exceptional antibiotics of the peptide groups. The test microorganisms acquired temporary resistance to enduracidin. However, the resistance is not likely to be the consequence of mutation, unless the mutant had an unusually high frequency of reverse mutation, since this resistance was highly labile and readily declined during incubation on an enduracidin-free medium. This fact suggests that staphylococci resistant to enduracidin will not readily appear in the field, as observed in the case of some other peptide antibiotics.

There were some differences among the $\mathrm{ED}_{50}$ obtained in the main experiment (shown in Table 1) and those in preliminary experiments, without regard for the similar body weight of mice used in these experiments. So it is considered that the measured effective dose fluctuates under the influence of unknown factor(s), presumably the virulence of bacterial population cultured in each experiment. Taking this fluctuation into account, the $\mathrm{ED}_{50}$ of enduracidin is thought to fall into a range not far from the measured confidence limits of $1.69 \sim 3.06 \mathrm{mg} / \mathrm{kg}$ obtained in the main experiment. Some authors ${ }^{2)}$ reported the in vitro effect of enduracidin on the protection against $S$. aureus infection, and showed the $\mathrm{ED}_{50} 3.2 \mathrm{mg} / \mathrm{kg}$ in subcutaneous treatment and $\mathrm{ED}_{50} 1.98 \mathrm{mg} / \mathrm{kg}$ in intraperitoneal treatment. Their method was not quantitative one but these values also support our assumption mentioned above.

\section{References}

1) Nakazawa, S.; H. Ono, R. Seda, Y. Todo, K. Suminito \& K. Nagase : Bacteriological studies on enduracidin, a new antibiotic substance. Chemotherapy (Japan) $16: 451 \sim 459,1968$

2) Goto, S.; S. Kuwabara, N. Окubo \& H. Zenyoji : In vitro and in vivo evaluation of enduracidin, a new peptide antibiotic substance. J. Antibiotics $21: 119 \sim 125,1968$

3) Special edition for enduracidin. Chemotherapy (Japan) $16: 451 \sim 672,1968$

4) Litchfield, T. \& F. Wilcoxon: A simplified method of evaluating dose effect experiments. J. Pharmacol. Exp. Therap. $96: 99 \sim 113,1949$

5) Tanaka, T.; K. Watanabe, N. Osawa \& S. Mitsuhashi : Resistance patterns of staphylococci from fowl fed with dairy products containing mikamycin. Chemotherapy (Japan) 19:138 140, 1971 